\title{
PCR detection and typing of human papilloma virus DNA in squamous carcinoma of the cervix in a cohort of Sri Lankan women
}

\author{
Rajiva de Silva', K Karunaratne ${ }^{2}$, Lalitha N Mendis ${ }^{3}$, R Ramesh ${ }^{4}$ and VTK Chow ${ }^{5}$
}

\begin{abstract}
Objective To determine the prevalence of human papilloma virus (HPV) types 16 and 18 in squamous carcinomas of the cervix in Sri Lanka.
\end{abstract}

\section{Design Case control study.}

Setting One gynaecological unit at the Cancer Institute, Maharagama, Sri Lanka.

Patients 15 patients with squamous carcinoma of the cervix, and 15 age matched controls with histologically normal cervices.

Measurements DNA was extracted from paraffin embedded cervical biopsies. Polymerase chain reaction was performed on extracted DNA employing primers specific for HPV types 16 and 18.

Results HPV 16 DNA was detected in 11 out of 15 cervical cancer biopsies $(73.3 \%)$, in comparison with 3 out of 15 normal controls (20\%). HPV 18 was detected in 3 out of 15 cervical cancer biopsies, but not in a single control biopsy.

Conclusion Despite the limited number of cases in this cohort, this study supports the strong association between HPV 16 and squamous cancer of the cervix.

\section{Introduction}

Squamous carcinoma of the cervix is one of the commonest malignancies in women [1]. A number of studies have identified certain oncogenic types of human papilloma virus (HPV) in the cervices of patients with invasive carcinoma, and its precursor lesions, cervical intraepithelial neoplasia (CIN) 1, 2, and 3. Studies in the west [2], and in India [3] have shown that HPV type 16 could be detected in over $60 \%$ of patients with invasive cervical carcinoma, and HPV type 18 in about $10-20 \%$ [1]. HPV types 6 and 11 are virtually absent in cervical cancer but they predominate in the benign lesion, condylomata acuminata [4].

Squamous carcinoma of the cervix is the second most common malignancy among Sri Lankan women. However, no studies hitherto have been undertaken to evaluate the role of HPV in the development of carcinoma of the cervix in this country. The objective of the present study was to determine the proportion of squamous cervical cancers in Sri Lankan patients associated with HPV types 16 and 18 .

\section{Materials and methods}

Fifteen patients from the Cancer Institute, Maharagama, who had histologically diagnosed squamous cell carcinoma of the cervix were recruited for the study. A biopsy obtained from each cervical lesion was placed in formalin. Fifteen histologically normal cervical biopsies to be used as negative controls were supplied by Dr A de Tissera of the Department of Pathology, Medical Research Institute. They were matched for age against the cancer patients. All biopsies were embedded in paraffin. Three micrometre sections were cut, fixed onto slides and stained with haematoxylin and eosin. To prevent cross contamination, a new blade was used and washed thoroughly with acetone after cutting each sample. An experienced histopathologist examined the sections for evidence of invasive squamous cell carcinoma. DNA was extracted from the 15 cancer specimens and the 15 controls, using a modification of a method described previously [5].

The positive control DNA for HPV 18 was the HeLa cell line, which contains 10-50 copies of the integrated virus per cell [6]. The negative control was the RD cell line, obtained from Dr. N Withane of the Department of Virology, Medical Research Institute, Colombo. DNA was extracted using a modification of the method described previously [7]. The positive control for HPV 16 was DNA extracted from the $\mathrm{SiHa}$ cell line.

Amplification of the DNA was performed using the polymerase chain reaction (PCR) technique $[6,8]$. The PCR employed primers which flank the E6 genes of HPV 16 [6] and HPV 18 [8], from the Bioprocessing Technology Centre, National University of Singapore. PCR was performed with the Dynazyme II DNA polymerase kit (Finnzymes OY Finland) using $0.1 \mu \mathrm{g}$ of each genomic DNA sample as a template. $1 \mu \mathrm{M}$ of each HPV 16 primer [6] and $2.5 \mu \mathrm{M}$ of each HPV 18 primer [8] was used in the reaction mixture.

The DNA polymerase provided in the kit was used at a concentration of 2.5 units per $50 \mu 1$ reaction volume. The buffer provided by the kit contained $10 \mathrm{mM}$ Tris- $\mathrm{HCl}$,

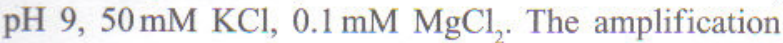
cycles for HPV 16 were performed at $95^{\circ} \mathrm{C}$ for $2 \frac{1}{2} \mathrm{~min}$ utes (denaturation), $65^{\circ} \mathrm{C}$ for 3 minutes (annealing) and $72^{\circ} \mathrm{C}$ for 3 minutes (extension) [6]. The cycling profile for HPV 18 included denaturation $\left(95^{\circ} \mathrm{C}\right)$, annealing

Departments of 'Immunology, and ${ }^{4}$ Molecular Biology, Medical Research Institute, Colombo 8. ${ }^{2}$ Cancer Institute, Maharagama. ${ }^{3}$ Faculty of Medicine, Colombo. ${ }^{5}$ Faculty of Medicine, Department of Microbiology, National University of Singapore.

Correspondence: R de S, e-mail: <nilhanrajivadesilva@yahoo.com> (Competing interests: none declared). Received 7 November 2005 and revised version accepted 6 May 2006. 


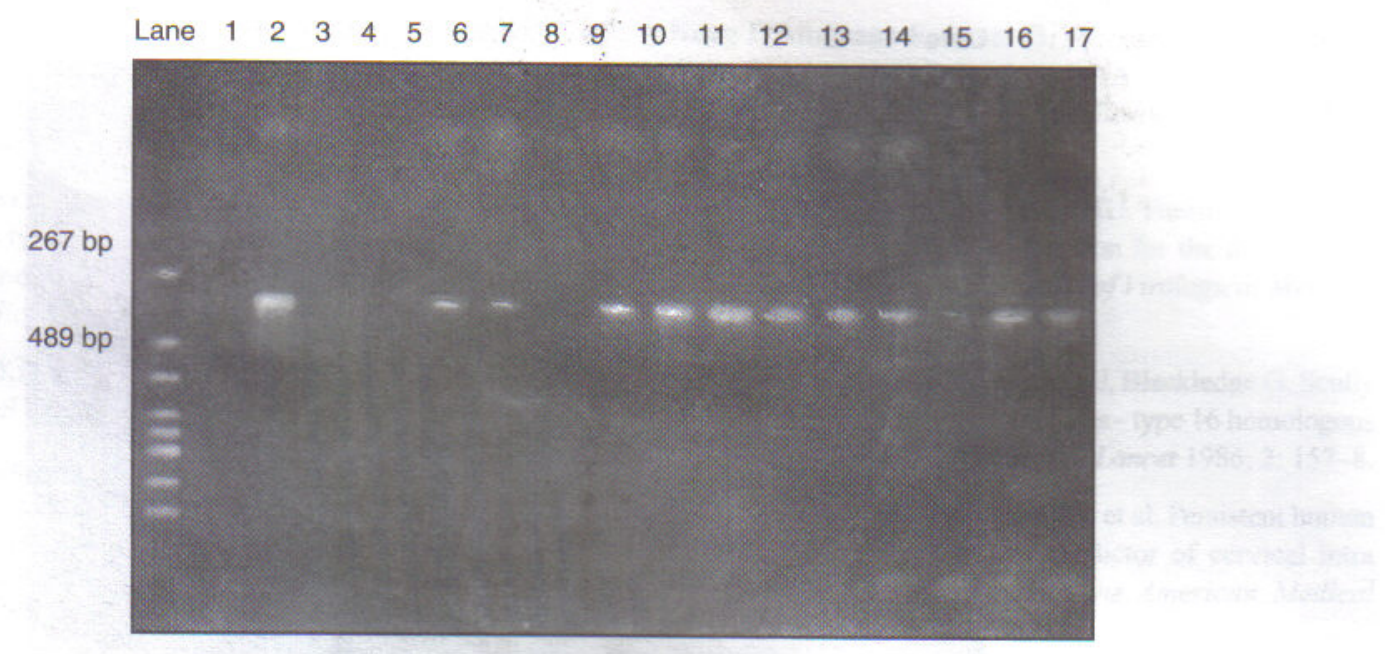

Figure 1. HPV 16 DNA in cervical cancer. Lane 1-DNA marker; Lane 2-Negative control; Lane 3-Positive control; Lane 4 to $17-$ Samples 1 to 14.

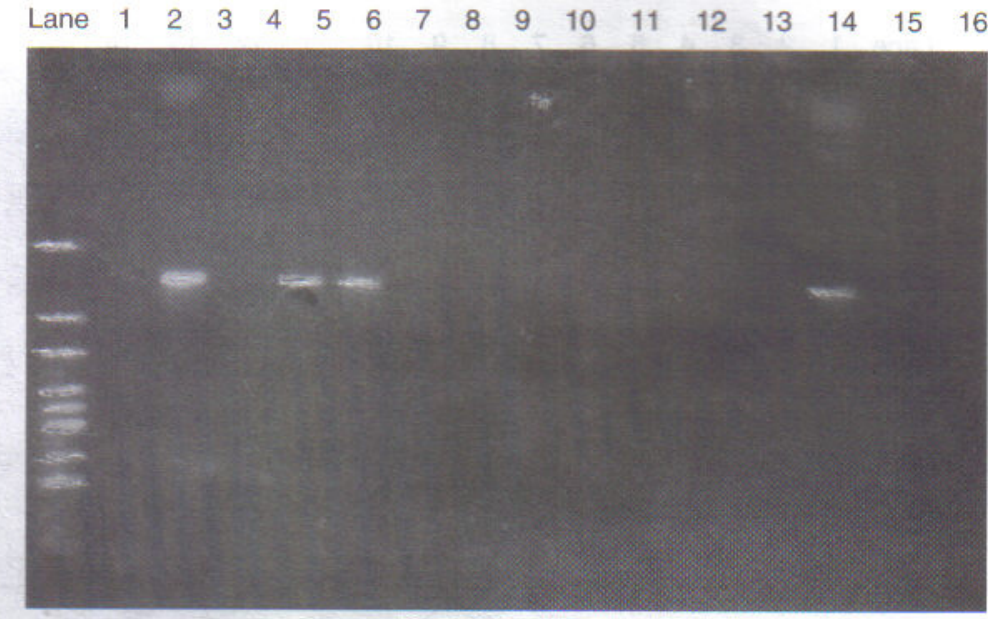

Figure 2. HPV 16 DNA in normal cervices. Lane 1-DNA marker; Lane 2-Negative control; Lane 3-Positive control; Lane 4 to 16-Samples.

$\left(60^{\circ} \mathrm{C}\right)$, and extension $\left(70^{\circ} \mathrm{C}\right)[8]$ for 3,4 and 4 minutes respectively. After 40 cycles, a final extension of $10 \mathrm{~min}-$ utes was carried out for both reactions. A thermal cycler (TSR 300, Iwaki Glass Co, Tokyo, Japan) was employed for the reaction. Positive and negative controls were used in each reaction. The PCR products were visualized by ethidium bromide staining after electrophoresis in a $3 \%$ agarose gel (Sigma). The PCR products were identified by size determination using the DNA marker $\mathrm{pHY}$.

Approval for this study was obtained from the Ethical Review Committee of the Faculty of Medicine, University of Colombo.

\section{Results}

The PCR products were visualized by viewing under UV light. The position of each band was compared with the positions of the positive control bands and the DNA marker. The HPV 16 target band is 334 bp [6], while the HPV 18 target band is $154 \mathrm{bp}$ [8]. HPV 16 DNA was detected in 11 out of 15 patients (73.7\%) (Figure 1) and in 3 out of 15 controls ( $20 \%$ ) (Figure 2 ). HPV 18 DNA was identified in 3 patients $(20 \%)$ (Figure 3), while none of the controls was positive (Figure 4). Mixed infection was detected in 3 patients (Table).

\section{Discussion}

In our study, there was a strong correlation between HPV 16 and cervical cancer in Sri Lanka. This finding is consistent with studies in the west and in Asia [2, 3]. For example, studies in India [3], and Hungary [2], detected HPV 16 in $82.4 \%$ and $64.8 \%$ of invasive squamous cervical cancers. The corresponding positivity rates for HPV 18 were $5.8 \%$ and $32.4 \%$. There was, however, no clear cut relationship between HPV 18 and squamous cervical cancers in our study. A larger cohort of samples is necessary to clarify the degree of this relationship.

Three of the $15(20 \%)$ patients had mixed infections. HPV 18 is linked to adenocarcinoma of the cervix [1], 


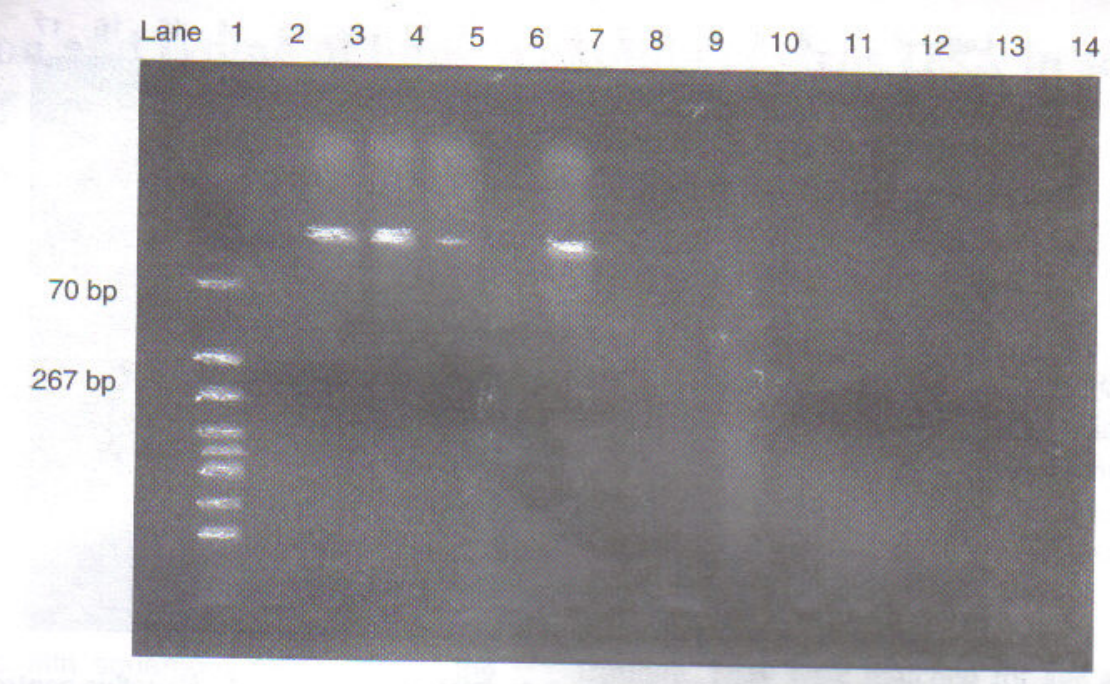

Figure 3. HPV 18 DNA in cervical cancer. Lane 1-DNA marker; Lane 2-Negative control; Lane 3-Positive control; Lane 4 to 14-Samples.

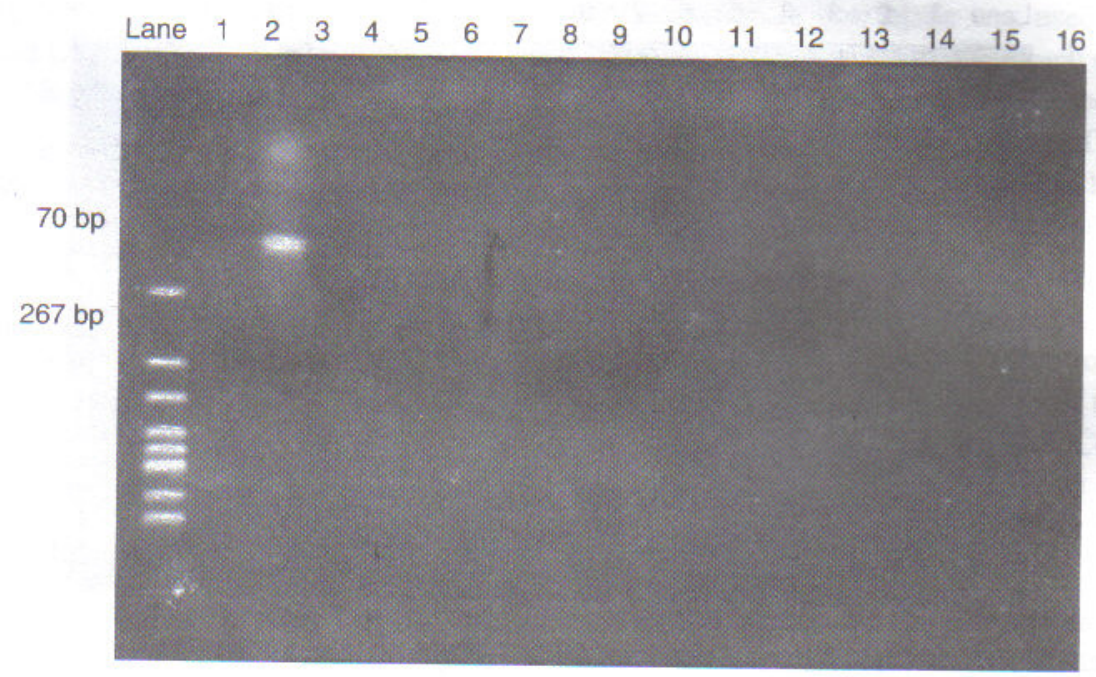

Figure 4. HPV 18 DNA in normal cervices. Lane 1-DNA marker; Lane 2-Negative control; Lane 3-Positive control; Lane 4 to 16 -Samples.

Table. Prevalence of HPV 16 and 18 DNA in cervical samples from Sri Lanka

\begin{tabular}{lcc}
\hline HPV type & $\begin{array}{c}\text { Squamous carcinoma } \\
\text { sample }(n=15)\end{array}$ & $\begin{array}{c}\text { Normal control } \\
(n=15)\end{array}$ \\
\hline 16 & 11 & 3 \\
18 & 3 & 0 \\
\hline
\end{tabular}

a histological type associated with a grave prognosis. Of the 3 patients with HPV 18 in our study, one patient was in her early forties, while the other two were in their fifties. A significant number of normal cervices harboured HPV $16(20 \%)$. This finding is consistent with results in other studies [9].

Prospective studies have shown that the risk of developing cervical cancer increases with persistent long term infection with "high risk" HPV types [10]. As our study and previous studies [2,3] have shown, DNAs of certain "high risk HPV types" such as types 16 and 18 are present in a majority of invasive cancers and in precursor lesions. In addition, a substantial number of apparently normal cervical smears shown by PCR to contain DNA of high risk HPV types, were shown by colposcopy to have underlying CIN 2 and CIN 3 [11].

\section{Acknowledgements}

We thank Dr A de Tissera, Dr N Withane, Mrs K Gunasekera and Miss DM Kadahettigae for assistance during the course of the study. This study was supported by a grant from NARESA (RG/95/M/7).

\section{References}

1. Franco EL, Schlecht NE, Saslow D. The epidemiology of cervical cancer. Cancer Journal 2003; 9: 348-59. 
2. Konya J, Veress G, Hernadi Z, Soos G, Czegledy J, Gergely L. Correlation of human papillomavirus 16 and 18 with prognostic factors in invasive cervical neoplasias. Journal of Medical Virology 1995; 46: 1-6.

3. Sarkar S, Verma K, Kaur H, Seth P. Detection of human papillomavirus types 16 and 18 DNA in cervical lesions of Indian women using in situ hybridization. Indian Journal of Medical Research 1992; 96: 356-60.

4. Roman A, Fife KH. Human papillomaviruses: are we ready to type? Clinical Microbiology Reviews 1989; 2: 166-90.

5. Goelz SE, Hamilton SR, Vogelstein B. Purification of DNA from formaldehyde fixed and paraffin embedded human tissue. Biochemical and Biophysical Research Communications 1985: 130: 118-26.

6. Chow VTK, Tay SK, Tham KM, Lim-Tan SK, Bernard HU. Subclinical human papillomavirus infection of the male lower genital tract: Colposcopy, histology and DNA analysis. International Journal of STD and AIDS 1991; 2: $41-5$.
7. Krieg P, Amtmann E, Sauer G. The simultaneous extraction of high molecular weight DNA and of RNA from solid tumours. Analytical Biochemistry 1983; 134: 288-94.

8. Chow VTK, Tham KM, Bernard HU. Thermus aquaticus DNA polymerase catalysed reaction for the detection of human papillomaviruses. Journal of Virological Methods 1990; 27: 101-12.

9. Cox MF, Meanwell CA, Maitland NJ, Blackledge G, Scully C, Jordan JA. Human papillomavirus - type 16 homologous DNA in normal human ectocervix. Lancet 1986; 2: 157-8.

10. Schlecht NF, Kulaga S, Lobitaille J, et al. Persistent human papillomavirus infection as a predictor of cervical intra epithelial neoplasia. Journal of the American Medical Association 2001; 286: 3106-11.

11. Cuzick J, Terry G, Ho L, Hollingworth T, Anderson M. Human papillomavirus type 16 DNA in cervical smears as predictor of high grade cervical intraepithelial neoplasia. Lancet 1992; 339: 959-60.

\section{Deeper lessons from the CMAJ debacle}

We believe the appropriate standard in judging whether a conflict is about editorial independence is whether an alternative compelling explanation is available. In the CMAJ case, no such explanation has been forthcoming. Without fair processes to protect editorial independence, the burden of proof should be on medical journal publishers to show that the termination was not a result of displeasure with editorial decisions. We believe that if CMA cannot offer an alternative compelling explanation other than editorial independence, it should offer to reinstate Hoey and Todkill* and subsequently follow its own interim governance principles.

(*Fired Editor-in-Chief and Deputy Editor)

Editorial comment. The Lancet 2006; 367: 1551 